\title{
A RESPONSABILIDADE DO SÓCIO NÃO ADMINISTRADOR NA SOCIEDADE LIMITADA COM FUNDAMENTO NO DEVER DE FISCALIZAR AS ATIVIDADES DO ADMINISTRADOR
}

\section{ARTIGO ORIGINAL}

JÚNIOR, Paulo De Souza ${ }^{1}$

FAUTH, Gabriela ${ }^{2}$

JÚNIOR, Paulo De Souza. FAUTH, Gabriela. A responsabilidade do sócio não administrador na sociedade limitada com fundamento no dever de fiscalizar as atividades do administrador. Revista Científica Multidisciplinar Núcleo do Conhecimento. Ano 05, Ed. 06, Vol. 10, pp. 05-27. Junho de 2020. ISSN: 2448-0959, Link de acesso: https://www.nucleodoconhecimento.com.br/lei/sociedade-limitada

\section{RESUMO}

Este estudo objetiva averiguar a aplicação da Teoria da Desconsideração Jurídica em face do sócio não administrador de sociedade limitada, analisando a possibilidade (ou não) de execução de bens de sócio que não exerce a administração da empresa. $A$ pesquisa se classifica como dedutiva e comparativa pautada na revisão bibliográfica e documental. Aborda-se, brevemente, as peculiaridades das sociedades limitadas, identificando, ainda, suas principais características e aspectos relativos à sua administração, tratando, nesse âmbito, a problemática da responsabilização do sócio não administrador segundo a doutrina e jurisprudência brasileira. Os principais

\footnotetext{
${ }^{1}$ Mestrado em Mediação e Resolução de Conflitos pela Universidad Europea Del Atlântico, Pós-Graduado pela Escola de Magistratura do Estado do Espírito Santo, Bacharel em Direito pela Faculdade de Direito de Cachoeiro de Itapemrim-ES (FDCl). 2 Doutorado em Direito Público. Mestrado em Derecho Ambiental (90 créditos) acesso ao doutorado. Mestrado em Urbanismo, História e Arquitetura da Cidade. Graduação em Direito.
} 
resultados auferem que, em tese, o sócio não administrador não pode ser responsabilizado por dívidas sociais, até porque a desconsideração da personalidade jurídica é medida excepcional. Porém, como se demonstrou, caso haja abuso no uso da pessoa jurídica, não apenas o administrador responderá, mas também os demais sócios. Contudo, tal análise demandará atenta verificação dos fatos no caso concreto, sendo somente assim que se poderão reunir elementos para justificar a responsabilização (ou não) do sócio que não exerce cargo de administração na sociedade limitada.

Palavras-chave: Responsabilidade do Sócio, Desconsideração da Personalidade Jurídica, Sociedade Limitada, Sócio Não-Administrador, dever de fiscalizar.

\section{INTRODUÇÃO}

A importância das empresas para o fomento da economia do país é inegável, ganhando relevo principalmente quando se trata das sociedades limitadas, pois, em tal modalidade empresária, a responsabilidade patrimonial de seus sócios, no caso de dívidas sociais, limita-se ao importe do capital integralizado por ele para a formação do patrimônio da pessoa jurídica. Logo, tal modalidade empresária veio a se tornar predominante na economia brasileira. Entretanto, da mesma forma que tantos outros institutos criados pelo homem, a pessoa jurídica eventualmente é desvirtuada de seus propósitos, ou seja, torna-se um mecanismo fraudulento e lesivo a terceiros.

Nesse sentido, cabe reiterar, nessa reflexão, que as teorias voltadas à desconsideração da personalidade jurídica, conceito este originado do direito inglês e norte-americano, de onde se extraem suas principais características, que, por sua vez, são delineadas no Direito Inglês e no Direito Norte Americano, e, assim, percorreu longo caminho no ordenamento jurídico brasileiro, sendo fortalecida com os apontamentos doutrinários e jurisprudenciais ainda na década de 60 , e, a partir de então, tem se solidificado, embora tenha sido disciplinada pela legislação recentemente, como se vê no Código Civil de 2002, em seu Art. 50 e no Código de Defesa do Consumidor, no Art. 28. 
É, contudo, no âmbito do CDC que se encontra a consagração dessa linha teórica pelo direito brasileiro, na medida em que, por meio do mencionado dispositivo, restaram estabelecidos os requisitos de aplicação e suas consequências, autorizando o magistrado a afastar a personalidade jurídica da sociedade em casos específicos (de abuso de direito, de excesso de poder, de infração de dispositivos legais, do cometimento de fatos ou atos ilícitos ou da violação do instrumento social - estatuto ou contrato). Acrescenta, ainda, o referido dispositivo, que a desconsideração seja igual no caso de falência, ou, ainda, em estado de insolvência, inatividade ou encerramento das atividades empresariais em decorrência de má administração.

Em relação à disposição inscrita Art. 50 do Código Civil de 2002, tem-se que a desconsideração da personalidade jurídica pode ser aplicada em casos nos quais resta comprovado abuso da personalidade jurídica, por meio da constatação de confusão patrimonial ou desvio de finalidade. Nesse contexto, cabe inferir que comprovadas as situações fáticas, poderá o Juiz decidir, quer por requerimento da parte, quer pelo Ministério Público, nos casos em que couber a sua intervenção no processo, sobre a extensão dos efeitos de determinadas relações obrigacionais aos bens particulares dos administradores ou sócios da empresa.

Contudo, deve-se destacar, nesse trabalho, que tratando-se da sociedade limitada, resta um questionamento na doutrina e jurisprudência sobre o alcance da responsabilidade por dívidas sociais do sócio que não exerce a administração da empresa, estando focada nele a problemática identificada para o presente estudo, cujo objetivo é averiguar a aplicação da Teoria da Desconsideração Jurídica em face do sócio não administrador de sociedade limitada, analisando a possibilidade (ou não) de execução de bens de sócio que não exerce a administração da empresa. Em relação à metodologia, a pesquisa pode ser classificada, quanto ao método de abordagem, como dedutiva e comparativa no que tange ao método de procedimento.

A coleta de dados está pautada nas técnicas de pesquisa documental indireta, já que se busca na legislação, na doutrina, na jurisprudência, dentre outras fontes, elementos capazes de proporcionar compreensão do tema. Buscando-se proporcionar melhor apresentação, sugere-se a subdivisão da presente pesquisa em três seções. $\mathrm{Na}$ 
primeira delas o propósito é compreender peculiaridades da teoria sob análise (da desconsideração da personalidade jurídica), abordando o seu surgimento, conceito, teorias que buscam explicar a sua aplicação, bem como a positivação do instituto no direito pátrio, tal como regulamentado pelo Código de Processo Civil de 2015.

Já a segunda seção é dedicada à abordagem da execução dos bens do sócio não administrador, analisando-se, para tanto, aspectos relacionados ao surgimento das sociedades limitadas, suas principais características e a problemática da administração social. Por fim, na terceira e última seção, aborda-se a impossibilidade de execução do sócio não-administrador, buscando, na jurisprudência, os argumentos favoráveis e contrários.

\section{A TEORIA DA DESCONSIDERAÇÃO DA PERSONALIDADE JURÍDICA}

A teoria da Desconsideração da Personalidade Jurídica, cuja origem e principais características encontram-se no Direito Inglês e no Direito Norte Americano, percorreu longo caminho no ordenamento jurídico brasileiro, sendo fortalecida com o trabalho doutrinário de Rubens Requião, ainda na década de 1960, e jurisprudencial, a partir de então, embora somente tenha sido disciplinada pela legislação recentemente, como se vê no Código de Defesa do Consumidor (Art. 28) e no Código Civil de 2002 (Art. 50). A doutrina aponta como origem da Teoria da Desconsideração da Personalidade Jurídica o Direito Inglês, e, nesse, impera o sistema do Common Law, cuja fonte do direito é o costume. Assim, a questão foi suscitada no ano de 1897, no julgamento do caso Salomon vs. Salomon \& Co. Ltd. (GUIMARÃES, 1998).

Nesse sentido, os ensinamentos de Ramos (2014) auferem que a doutrina da desconsideração (disregarddoctrine) é oriunda de construção jurisprudencial, principalmente das jurisprudências norte-americana e inglesa, sendo atribuído, a este caso, o pioneirismo nas tratativas sobre a teoria da Desconsideração da Personalidade Jurídica. A decisão proferida pela Câmara de Lordes (House of Lords) é de suma importância para o Direito Comercial Inglês, pois fixou dois princípios básicos à teoria em comento, quais sejam: a) a divergência entre a pessoa jurídica da 
sociedade e a dos sócios; b) a legitimação da sociedade de uma só pessoa. Importante ressaltar que já se admitia a personalidade jurídica da empresa como uma realidade, principalmente porque a limitação da responsabilidade dos sócios era reconhecida (GUIMARÃES, 1998).

Porém, deve-se destacar, aqui, que após o caso Salomon vs. Salomon \& Co. Ltd. passou-se a reconhecer como absoluta a personalidade jurídica da sociedade, e, desse modo, manifesta-se de forma independente à personalidade dos sócios, embora inexistisse legislação à respeito (GUIMARÃES, 1998). A sociedade Salomon \& Co. Ltd., como aponta Silva (2009), foi criada no ano de 1892, por Aron Salomon, e era formada por ele e seus familiares, cuja maior parte do capital concentrava-se nas mãos de Aron. Tal característica demonstra que a sociedade era fictícia, pois havia apenas um sócio, tanto que Aron Salomon constitui um crédito privilegiado em favor de si mesmo, e, então, recebeu grande quantia em dinheiro e, ante a insolvência da companhia, restou os credores quirografários, sem qualquer garantia (SILVA, 2009).

Diante da Corte de Apelações o liquidante da Companhia alegou, em favor dos credores, que a sociedade era agente da atividade de Salomon, tendo o juízo acatado tal alegação (SILVA, 2009). A Câmara de Lordes, porém, decidiu que o negócio era legítimo e que o objetivo da sociedade não era servir de agente para os atos dos sócios, reformando o entendimento da Corte de Apelações (SILVA, 2009). Diante da insolvência e dissolução da Salomon \& Co. Ltda. é que se estabeleceu o litígio judicial entre o próprio Aron Salomon, liquidante da sociedade, e a sua sociedade. E que, nas instâncias inferiores, os julgadores deram ganho de causa à sociedade, condenando o sócio majoritário a pagar-lhe certa quantia em dinheiro, ressaltando as decisões de que a sociedade seria apenas mais um nome para designar o próprio Aron Salomon, o que justifica a expressão "agente" que lhe conferiu a Corte de Apelações (SILVA, 2009).

Porém, a House of Lords (Câmara de Lordes) não entendeu dessa forma e reformou a decisão proferida nas instâncias inferiores, sob o argumento de que uma vez admitida a existência da sociedade por seu liquidante, passa-se a fazer valer determinados direitos contra seu sócio principal em decorrência da distinção entre as 
personalidades da sociedade e dos sócios. Asseverou a Câmara de Lordes, ainda, que o fato de estarem quase todas as ações no nome de Aron Salomon não era suficiente para afetar a validade da constituição da sociedade, nem mesmo de fazer nascer, contra a pessoa de seus sócios, deveres conexos (SILVA, 2009). Percebe-se, portanto, que a decisão da Câmara de Lordes não aplicou a desconsideração da personalidade jurídica, e, como disserta Silva (2009), apresenta-se como influência negativa para o desenvolvimento da Disregard Doctrine, embora tenha contribuído para a aplicação rigorosa dos princípios da separação das personalidades jurídicas entre sócios e sociedade, bem como da responsabilidade patrimonial nela consagrada (SILVA, 2009).

Por sua vez, Coelho (2014) preconiza que a efetiva contribuição para o surgimento e consolidação da teoria da Desconsideração da Personalidade Jurídica advém de Rolf Serick, pois defendeu, no ano de 1953, sua tese de doutorado sobre a temática, embora não se possa ignorar que outros autores, a exemplo de Maurice Worm que, já na década de 1920, já havia tratado do tema, sendo concebido, portanto, como precursor de Serick, embora seja este, no entender do autor, quem efetivamente buscou na jurisprudência norte-americana os critérios para definir a teoria em comento. Percebe-se, portanto, que a teoria surgiu na jurisprudência, embora os estudos doutrinários sejam de suma importância para o seu aperfeiçoamento e consolidação. Anote-se, ainda, que não há na legislação um conceito de desconsideração da personalidade jurídica, ficando à cargo da doutrina a delimitação do instituto.

Nesse contexto, sobre a conceituação do instituto, cabe ressaltar que, no plano conceitual, a desconsideração da personalidade jurídica é o instituto por meio do qual o juiz deixa de levar em conta a separação/autonomia patrimonial existente entre sociedade e sócio(s) com o fim de responsabilizar este(s) por dívidas daquela. Coelho (2014), por sua vez, direciona os apontamentos para o fato de que a teoria da Desconsideração da Personalidade Jurídica é uma elaboração doutrinária recente, destacando, contudo, o surgimento no âmbito jurisprudencial. Coelho (2014) defende que no ordenamento jurídico pátrio encontram-se duas teorias acerca da 
desconsideração, uma maior e uma menor. A teoria maior, também denominada subjetiva, segundo o autor supracitado, tem base sólida e se refere à verdadeira desconsideração, e, ainda, vincula-se na verificação do uso fraudulento da pessoa jurídica.

Assim, para ser aplicada, exige-se a presença (concomitante) de dois requisitos, quais sejam, o prejuízo ao credor e o abuso da personalidade jurídica. Por outro lado, a teoria menor, ou objetiva, aplica-se à qualquer situação, bastando a insolvência da sociedade, cuja fraude é presumida. Existe, pois, a exigência da presença de tão somente um elemento, qual seja, o prejuízo causado ao credor. No direito brasileiro, de acordo com Tartuce (2015), a teoria maior ampara-se no Art. 50 do Código Civil de 2002, ao passo que a teoria menor tem sua incidência no Art. 28 do Código de Defesa do Consumidor. Analisando os pressupostos de ambas, tem-se que a teoria menor da desconsideração aponta como elemento para a sua aplicação o simples inadimplemento do crédito constituído pela pessoa jurídica, impondo a superação da personalidade jurídica, em especial o princípio da separação patrimonial.

Há que se considerar a incidência de ausência de patrimônio da sociedade para solver crédito de terceiro juntamente com a existência de sócio com solvabilidade, fatos que devem ser demonstrados pelo detentor do crédito junto à sociedade. De outro lado, a teoria maior é a que abrange, no direito pátrio, um maior número de adeptos, principalmente porque é a linha teórica mais próxima dos moldes originais estabelecidos para o instituto nos direitos norte-americano e inglês, alcançando outros países da Europa com o passar dos tempos. A teoria maior possui grande semelhança com a formulação objetiva, pois permite o requerimento da desconsideração ao juiz em situações nas quais a sociedade empresária seja utilizada para fins de abuso de direito ou cometimento de fraude. É considerada uma teoria mais elaborada e precisa por não depender de qualquer implemento legislativo para sua admissão eis que possui o escopo de reprimir atos fraudulentos.

Ou seja, a inexistência de preceito legal expresso não impede sua aplicação, já que atitude deste porte importaria em amparo à fraude. Coelho (2014), ainda, defende que a Teoria Maior é alvo de severas críticas, principalmente porque não há distinção entre 
a desconsideração e outros institutos, como a fraude a credores, a responsabilização subsidiária, a irregular dissolução da sociedade, dentre outros, bastando tão somente a insolvência da sociedade para fazer com que os bens dos sócios venham a responder pelas obrigações sociais, não importando a configuração dos atos como abuso de direito ou fraude. Cumpre destacar que a teoria da Desconsideração da Personalidade Jurídica foi introduzida no Direito Brasileiro pela doutrina há algumas décadas, sem, contudo, deixar de fomentar discussões acirradas quanto à sua aplicação, questão que será mais bem explicitada no momento oportuno.

Não é demais frisar que a jurisprudência, na esfera cível, há muito já reconhece a possibilidade de afastamento da personalidade jurídica perante determinados casos concretos, responsabilizando os sócios pelos atos cometidos por meio da pessoa jurídica, muito embora o texto do Código Civil de 1916 fosse omisso sobre a questão. Com o advento do Código Civil de 2002, o legislador reconheceu expressamente que havendo abuso da personalidade jurídica, por meio da confusão patrimonial ou do desvio de finalidade, pode o magistrado, a requerimento da parte ou do representante do Ministério Público, em casos nos quais lhe cabe intervenção no processo, estender determinadas obrigações aos administradores ou sócios da pessoa jurídica, nos termos do Art. 50 do Código Civil.

Desta feita, deve-se frisar, considerando o contexto apresentado, que apenas é possível ao magistrado desconsiderar a personalidade jurídica ante o reconhecimento de que a pessoa jurídica não se confunde com os seus membros, e, desse modo, as reflexões de Silva (2009) apontam tal prerrogativa como de suma importância à aplicação e efetividade da teoria. Cabe ressaltar, também, mediante o exposto, que o Código Civil brasileiro, especialmente o seu Art. 50, possibilita a aplicação da desconsideração da personalidade jurídica em casos de abuso desta, e, para tanto, essas situações precisam estar marcadas pelo desvio de finalidade da atividade empresarial, ou, ainda, por meio da confusão patrimonial / patrimônio dos sócios e da empresa. Assim sendo, alude-se que:

Art. 50. Em caso de abuso da personalidade jurídica, caracterizado pelo desvio de finalidade, ou pela confusão patrimonial, pode o juiz decidir; a 
requerimento da parte ou do Ministério Público, quando Ihe couber intervir no processo, que os efeitos de certas e determinadas relações de obrigações sejam estendidos aos bens particulares dos administradores ou sócios da pessoa jurídica (BRASIL, 2002).

Ao dissertar sobre o referido dispositivo, Venosa (2013) destaca que a redação atende à necessidade do magistrado, na análise do caso concreto, de retirar o véu que encobre a pessoa jurídica para que seja possível atingir igualmente os sócios controladores ou administradores em casos nos quais reste constatado desvio de finalidade, com consequente prejuízo causado à terceiros em decorrência disso. Nesses casos, conforme o autor, pode o juiz determinar que se estendam os efeitos de determinadas relações obrigacionais para atingir os bens particulares dos sócios administradores. Vale lembrar que nos termos dos ditames incluídos nos Arts. 28 do Código de Defesa do Consumidor Brasileiro e 50 do Código Civil de 2002, a "[...] sociedade empresarial figura como devedora e os sócios, como responsáveis patrimoniais secundários, ou seja, mesmo não sendo devedores, responderão com o seu patrimônio pela satisfação da dívida" (NEVES, 2015, p. 198).

Da análise do artigo do codex consumerista, constata-se que o abuso de direito é fator motivador da aplicação da desconsideração da personalidade jurídica. Da análise da segunda parte, verifica-se, ainda, a possibilidade de assim agir, como aponta Silva (2009), em casos em que a responsabilização do sócio ou administrador for necessária por falência, insolvência, encerramento ou inatividade da sociedade, desde que oriundos da má administração. Há, ainda, a possibilidade de se responsabilizar os sócios ou administradores, desde que presente a má administração no que tange à própria pessoa jurídica e aos demais sócios, o que demonstra não ser apenas o consumidor o objeto da tutela conferida pelo Código de Defesa do Consumidor Brasileiro. Por fim, o $\S 5^{\circ}$ do Art. 28 do CDC aponta a existência de certa incerteza em relação à insatisfação do consumidor como justificativa para se aplicar a desconsideração da personalidade jurídica. 


\section{DAS SOCIEDADES LIMITADAS: CONSIDERAÇÕES GERAIS}

Foi em razão das necessidades de pequenos e médios empresários que surgiu este novo tipo societário, pois ele consegue reunir as vantagens das sociedades de capitais e da sociedade de pessoas, assegurando, para tanto, aos sócios, a responsabilidade limitada apenas pelas obrigações sociais (TOMAZETTE, 2003). Nesse sentido, tornase relevante destacar que foi o relacionamento pessoal combinado com a junção de esforços e bens para alcançar determinado fim que deram origem às primeiras manifestações voltadas à criação das sociedades com o intuito personae, ou seja, aquelas que compreendem a união das qualidades pessoais dos respectivos sócios, com destaque e predominância dos elementos subjetivos (ALMEIDA, 1998).

Como era de se esperar, houve, então, uma intensa evolução econômica em função de um progresso contínuo dos negócios, vindo a obrigar, por volta do século $\mathrm{XV}$, a necessidade de maiores volumes de capitais necessários à formação das empresas, surgindo, assim, as sociedades de capital, para as quais se considera o ingresso de cada sócio, anônimas, com uma constituição rebuscada, com o fim de empreendimentos de grande monta (ALMEIDA, 1998). A Alemanha, contudo, foi o berço da sociedade limitada. No entanto, cabe aludir que esse tipo societário não nasceu com essa denominação, uma vez que antes era denominada sociedade por quotas de responsabilidade limitada, tal como estabelecido em lei datada de 20 de abril de 1892.

Contudo, desenvolveu-se de forma extraordinária no Brasil, visto que acabou tornando-se o tipo empresarial mais comum, preferido, portanto, por não empresários e empresários, cujas atividades poderiam ser de pequeno, grande e médio porte (NEGRÃO, 2005). Nesse contexto, destaca-se o projeto do então Deputado Joaquim Luís Osório que teve uma tramitação bastante rápida, descartando a possibilidade de maiores debates ou alterações em seu texto por parte da Câmara Legislativa, o que veio a dar origem ao Decreto № 3.708 de 10/01/1919, com apenas dezoito artigos, com determinação, no último deles, de aplicação subsidiária da lei das sociedades anônimas, no caso de omissões referentes aos contratos e à lei (CARVALHOSA, 2005). 
Pode-se dizer que, de certa forma, há um ponto positivo, principalmente no tocante ao uso de lei subsidiária, pois foi tal lacuna que garantiu a flexibilidade para impulsionar a autonomia do interesse dos sócios por meio do contrato social (CARVALHOSA, 2005). Foi justamente esta flexibilidade, em conjunto com a limitação da responsabilidade dos sócios, que tornou limitado o tipo societário por excelência da pequena e média empresa brasileira e, desse modo, a partir dos anos 80 , também das grandes empresas, especialmente das multinacionais. Enfim, o Código Civil de 2002 estabeleceu um sistema diferenciado e unificado para as sociedades de um modo geral, constando disposições em seu capítulo IV acerca da sociedade limitada.

Sendo assim, o referido codex civil brasileiro trouxe algumas adaptações que pudessem atender as exigências do Decreto 3.708/19, pois havia certas lacunas, dando à Sociedade Limitada mais autonomia e uma estrutura peculiar, cuja disciplina, sua forma de constituição e o seu funcionamento, transformando-o em um tipo societário ímpar, atribuíram mais segurança jurídica para os que de uma forma ou de outra estabelecem negócios para com este tipo societário, bem como a sua nova denominação que muda de "Sociedade por quotas de responsabilidade limitada" para apenas sociedade limitada (CARVALHOSA, 2005). Tendo em vista o decorrido acerca da historicidade da sociedade limitada, não menos importantes são as características que devem ser ressaltadas, objeto do próximo item.

Dentre as inúmeras características peculiares que possuem os tipos empresários, cabe destacar, nessa reflexão, que será restrito o destaque para algumas por entender-se serem as de maior relevância para a caracterização da sociedade limitada. Uma de suas mais importantes características é o fato de poder ser formada pela reunião de pessoas físicas ou pessoas jurídicas, atribuindo-se a responsabilidade a cada sócio na medida de sua quota parte, muito embora todos respondam solidariamente pela integralização do capital social. De igual modo, tem-se o resguardo do patrimônio pessoal dos sócios, não vindo estes a responder por dividas sociais oriundas do insucesso da empresa, salvo nas exceções previstas em lei (CARDOSO, 2012). 
Neste sentido, Campinho (2011, p. 142) disserta que "como em todas as sociedades empresárias, o perfil característico da sociedade limitada repousa na responsabilidade do sócio perante terceiros, credores da pessoa jurídica”. Em face da sociedade, cada sócio quotista é obrigado a entregar tão somente o valor de sua cota. Integralizando este valor, não deverá ele mais nada à sociedade. Contudo, perante terceiros, todos os sócios irão responder, de forma solidária, pela parte que faltou integralizar. Quanto à responsabilidade dos sócios em relação à sociedade limitada, pode-se entender então que este tipo societário adotou para si, como regra principal, o fato de que, estando o capital social uma vez integralizado tal qual disposto no contrato por todos os sócios, ficarão eles eximidos de qualquer responsabilidade, nada mais devendo à sociedade de forma individual, nem de forma solidária aos credores da pessoa jurídica (CAMPINHO, 2011).

Dessa forma, os credores deverão exaurir as possibilidades de ataque aos bens da sociedade primeiramente, já que a responsabilidade dos sócios é subsidiária, o que acarreta a responsabilização da sociedade com todo o seu patrimônio, diretamente por suas obrigações (CAMPINHO, 2011). Há que ressaltar que outra característica deste tipo societário é a de que os sócios podem possuir uma ou mais quotas, sendo estas de valores iguais ou distintos, porém o Código Civil adotou e manteve a indivisibilidade da quota, com a exceção no caso de transferência, tendo em vista que as quotas podem ser cedidas a outras pessoas mediante pagamento ou mesmo de forma gratuita, contudo, tem-se ressalva quanto à cessão de quotas, considerando-se que, no caso de o contrato social nada dispor sobre esta questão, ficará ela adstrita à aprovação de três quartos do capital social (TOMAZETTE, 2003).

Tendo em vista a análise feita acerca das características da sociedade limitada, que tem maior relevância, como visto, no que diz respeito à responsabilidade do sócio, sendo mister averiguar as questões afetas à administração social. A sociedade limitada é constituída por meio de um instrumento contratual denominado de contrato social, que foi criado a partir do Art. $2^{\circ}$ do Decreto $n^{\circ} 3.708$, e, assim, dispõe que o ato constitutivo regularizar-se-ia a partir do disposto nos Arts. 300 e 302, ambos do Código 
Comercial, em que constava sobre a limitação da responsabilidade dos sócios e ao capital social totalizado (REQUIÃO, 2003).

Nesse contexto, cabe ressaltar, aqui, que pode-se encontrar dispositivos legais que versam acerca da constituição da empresa no Código Civil, e, assim, cabe mencionar o Art. 997, pois estipula o conteúdo que deverá ter no supra contrato, que, por sua vez, são aspectos previstos para as sociedades simples e ainda inclui a firma social, caso seja necessário. Inclui, também, a característica principal que é a limitação da responsabilidade do sócio, e, por consequência, a responsabilidade solidária pela integralização do capital social (REQUIÃO, 2003). Nesse sentido, Cardoso (2012, p. 53) elucida que:

A sociedade limitada constitui-se por contrato escrito, particular ou público, que, além de cláusulas estipuladas pelas partes, mencionará se os sócios respondem, ou não, subsidiariamente, pelas obrigações sociais. A participação no capital social da limitada gera, por assim dizer, direitos e obrigações para os sócios.

Os sócios estão obrigados a integralizar o capital social subscrito no contrato, ou seja, a contribuir com capital que subscreveu para a formação da sociedade, a tempo e modo que foi estipulado no contrato, possuindo responsabilidade no limite da sua contribuição social (Art. 1.052 do Código Civil). O que se pode extrair disso é que se o sócio não responde com o seu capital particular, no caso de dívidas advindas da sociedade, significa que é com o nascer da sociedade, devidamente estipulado em contrato social, é que nascerá o patrimônio social, qual será o responsável e garantidor das dívidas advindas da sociedade (CARDOSO, 2012). Tem como requisito esses aspectos comuns à todos os contratos do gênero, em seu ato constitutivo o livre consentimento das partes, a capacidade das partes, a idoneidade do objeto (objeto lícito), a legitimação das partes para realizá-lo e a forma legal (CAMPINHO, 2011).

Além dos requisitos inerentes à todos os tipos de contratos sociais, a sociedade limitada possui, também, requisitos que Ihe são peculiares, sendo a pluralidade de sócios a contribuição de todos os sócios para a constituição do capital social, contudo, 
vale lembrar que este tipo societário não admite que o sócio integralize sua quota parte do capital a partir do trabalho, conterá, também, o numerário de participação nos lucros, com destaque para o Art 1.008 que veda a não distribuição dos lucros entre os sócios, ou seja, a centralização de lucros para apenas um sócio, já que este tipo societário tem como exigência a pluralidade de sócios, e, por fim, a chamada affectio societatis, ou seja, a vontade de se associar e se manterem unidos (CAMPINHO, 2011).

O ato constitutivo, como visto, tem o intuito de vincular juridicamente os sócios, e, para tal, estabelece diretrizes obrigacionais entre eles, tendo como escopo principal criar um sujeito de direitos e de personalidade jurídica, que, por sua vez, vem a ser uma das principais finalidades do ato, sendo essa a sociedade (CALÇAS, 2003). A partir do momento em que a constituição se concretizar a sociedade passará a atender por seu nome comercial, e, assim, poderá ter denominação particular ou razão social, conforme o descrito no contrato (REQUIÃO, 2003). Quando se trata de administração da sociedade, remete-se à uma pessoa, ou, no caso, pessoas, e, por sua vez, o administrador possui função precípua, como preceitua o Art. 1.011 do Código Civil.

Deve-se ter cuidado e diligência no exercício de suas funções, como se administrasse seus próprios negócios, tendo em vista que o Art. 1.016 do mesmo diploma define que os administradores respondem por culpa no desempenho de suas funções (CALÇAS, 2003). A administração social é incumbida a uma ou mais pessoas designadas no contrato social ou por ato separado. Esses administradores são eleitos pelos sócios e destituídos da mesma maneira, contudo, em cada situação, há que ser observado o disposto na lei, como a exemplo de exigibilidade de maioria qualificada (COELHO, 2014). Sobre esta questão, à luz do Código Civil, Carvalhosa (2005, p. 104) explica que "a sociedade limitada poderá ter um ou mais administradores, conforme livremente dispuser seu contrato social, não estabelecendo o Código Civil de 2002 números mínimo ou máximo".

O Código Civil regulou apena alguns aspectos relativos aos administradores, tais como a forma de sua nomeação, investidura, término do cargo, sua destituição e renúncia e o exercício e prestação de contas da administração da sociedade. As 
demais regras não especificamente tratadas deverão ser supridas pela aplicação das regras das sociedades simples ou das regras relativas às sociedades anônimas para as limitadas que assim optarem em seu contrato social. A administração da sociedade era cargo exclusivo de sócio, conforme os Arts. 10, 11, 12 e 13, do Decreto 3.708/19. Referiam-se ao sócio-gerente. Contudo, o Código de 2002 passou a permitir que os não-sócios pudessem ser nomeados, com observação à legislação que obriga a unanimidade dos sócios, caso o capital social não esteja integralizado. Caso esteja integralizado o capital social deverá observar o montante de 2/3 (dois terços), sendo este último o mínimo estipulado (CAMPINHO, 2011). Assim:

No Código Civil se estabelece a possibilidade de nomeação de estranho ao quadro social para as funções de administrador, por aprovação unânime dos sócios, quando o capital não estiver integralizado, e, após a integralização, por três quartos do capital social, não lhe sendo vedada a assunção dessas responsabilidades por parte de pessoa jurídica (NEGRÃO, 2005, p. 366).

E, ainda, Tomazette (2003, p. 177), de acordo com o novo conceito trazido pelo Código Civil de 2002, explica:

Com o Código Civil de 2002, a sistemática da gestão da sociedade limitada é profundamente alterada, sendo aperfeiçoada pelo novo diploma legal. Em primeiro lugar, admite-se que o contrato social expressamente permita a nomeação de administradores estranhos ao quadro social, facilitando a profissionalização da gestão. Entretanto, caso exista a permissão contratual, ainda assim, exige-se um quórum qualificado para a nomeação de tais estranhos, qual seja, a unanimidade enquanto o capital social não estiver totalmente integralizado, e dois terços do capital social após sua integralização, em função dos maiores riscos que podem advir da nomeação de um estranho.

Uma característica da administração na sociedade limitada é que este tipo societário admite apenas um administrador-diretor, seja ele sócio ou não, desde que eleito no 
contrato, sendo este o representante legal da empresa (PALMA, 2006). É o contrato social ou $\mathrm{o}$ ato de nomeação em separado que delimita o tempo que o administrador estará à frente da sociedade, podendo ser por tempo determinado ou indeterminado. Contudo, o tempo de duração da administração, de reeleição do administrador, caso haja, deverá ser arquivado na Junta Comercial (COELHO, 2014). Pode o administrador pedir a renúncia, porém tal ato gera efeitos de conhecimento imediato pela sociedade, mas, perante terceiros, o administrador renunciante continuará respondendo até que cesse o prazo legal do seu exercício, que deverá constar no registro público competente (NEGRÃO, 2005). Assim, Campinho (2011, p. 242) alude que:

Na circunstância de renúncia de administrador, deve a manifestação unilateral de sua vontade ser veiculada por escrito, ou traduzida em ata de assembleia ou reunião dos sócios, ou ainda em ata de reunião do órgão de administração. Em relação à sociedade, torna-se a renúncia eficaz a partir do momento em que a ela é dado conhecimento do ato volitivo expressado pelo renunciante. Porém, sua eficácia em relação a terceiros depende de averbação no registro da sociedade e, também, exige a lei, a realização de publicação, com o escopo de melhor proteger os interesses desses terceiros. A publicação far-se-á tanto no órgão oficial da União ou do Estado, conforme o local da sede da sociedade, bem como em jornal de grande circulação $\left(\S 3^{\circ}\right.$, do artigo $1.063 \mathrm{c} / \mathrm{c} \S 1^{\circ}$ do artigo 1.052).

No que tange às responsabilidades do administrador, há que se levar em consideração as obrigações contraídas dos chamados atos regulares e ordinários de gestão, do qual o administrador não responde por estes atos perante terceiros, pois têm-se que o administrador é um mero titular da sociedade, ou seja, quando ele está de posse do cargo a ele conferido não age em seu nome próprio e nem por conta própria, mas sim em nome da sociedade, manifestando de forma externa as vontades e necessidades dela, sendo responsável, nesse caso, a própria sociedade (CARVALHOSA, 2005). Nesse sentido, reforça Tomazette (2003, p. 179) que: 
Praticando atos que não extrapolem tais limites, os administradores praticam atos regulares de gestão, os quais são imputados à sociedade, e não a eles, uma vez que são, meros órgãos que fazem presente a vontade da sociedade. Tais atos são de responsabilidade exclusiva da própria sociedade, não havendo que cogitar de responsabilização do patrimônio do administrador.

Reiterando o expresso aufere-se que o administrador não responde quando os atos por ele praticados estiverem dentro dos limites e dos poderes a ele conferidos. Ocorre que quando o administrador age de maneira a não exercer seus poderes em benefício da sociedade, por motivos de vicissitudes pessoais, ou melhor, excedendo os poderes a ele conferidos, tais atitudes violam a lei ou as regras estipuladas no contrato social, sendo inequívoca, nesse caso, a imputação da responsabilidade a ele atribuída (TOMAZETTE, 2003). Dessa forma, para que o administrador não incorra no risco de ser responsabilizado pelos atos praticados, como dispõe o Art. 1.011 do Código Civil, ele deverá empregar cuidado e diligência na administração como se empregasse em interesse de seus próprios bens (CALÇAS, 2003).

Ocorre que, para tanto, os direitos do administrador estão ligados, intimamente, a obrigatoriedade da prática de seus atos com diligência, o que implica, portanto, tomar as devidas precauções no caso de compra ou venda de produtos e serviços, de forma a examinar preço e qualidade desses, e, por fim, não deve realizar atos que coloquem o interesse da sociedade em conflito, evitando, dessa forma, ser responsabilizado (CAMPINHO, 2011). Para tanto, os sócios podem se valer de um direito que possuem para evitar que ocorra o excesso de poderes atribuído ao administrador. Trata-se da fiscalização dos atos de administração ou conselho fiscal e este direito não poderá ser omitido nem proibido por contrato, assembleia geral ou reunião de cotistas (CAMPINHO, 2011).

É obrigatório, ao administrador, segundo o Art. 1.065 do Código Civil, que, ao final do exercício social administrativo, seja efetuado um levantamento do balanço patrimonial e um balanço dos resultados econômicos, deixando-os à disposição dos sócios, observando o prazo de 30 (trinta) dias antes da assembleia ou da reunião anual dos 
cotistas, dos quais irão apreciar sobre os atos do administrador e deliberar sobre os balanços, também disposto no Art. 1,078 do mesmo diploma legal (CAMPINHO, 2011). Deve haver uma interação das informações financeiras e negociais que serão claramente expostas no relatório da administração, devendo, inclusive, ser relacionados os investimentos da sociedade em controladas e coligadas e mencionadas as alterações ocorridas durante o exercício.

Em que pese à respeito da participação dos sócios, não há restrições quanto à possibilidade de participação de qualquer sócio quotista, porém no que tange à participar das deliberações, esta última estará de acordo com a parcela do capital que possui o sócio, com fundamento no princípio da maioria do capital social, cuja matéria se encontra disciplinada no Art. 1.072 do Código Civil (REQUIÃO, 2003). Contudo, as deliberações que tratem do funcionamento diário da sociedade não têm a forma como requisito essencial, já que algumas decisões poderão ser tomadas de maneira informal, em respeito ao princípio da celeridade, principalmente no que tange aos negócios de cunho mercantil que se tornam incompatíveis com um rito formal (REQUIÃO, 2003).

Não obstante, existem assembleias nas quais a pauta exigirá um quórum específico de sócios, bem como algumas formalidades a serem cumpridas, contudo este trabalho não irá destacar todas as formas previstas, tendo apenas uma breve noção de funcionamento da administração, responsabilidades e deveres.

\section{DA (IM) POSSIBILIDADE DE SE EXECUTAR OS BENS PARTICULARES DO SÓCIO QUOTISTA NÃO-ADMINISTRADOR}

A maioria absoluta das sociedades empresárias brasileiras utiliza-se do tipo limitada, enquanto nas restantes predomina a forma anônima. Logo, a aplicação da desconsideração nas sociedades anônimas está diretamente relacionada à ocorrência de abuso do poder de controle por parte do sócio administrador. A esse respeito, seguindo ensinamentos de Bruschi (2009, p. 144), tem-se que o sócio administrador, ou controlador, é "[...] a pessoa física, ou grupo de pessoas físicas, ou, ainda, pessoa jurídica, que detém o controle". Anote-se que dentre as hipóteses de 
aplicação relacionadas à Lei $\mathrm{n}^{0}$ 6.404/1976, que versa acerca das sociedades por ações, no Art. $244, \S 2^{\circ}$, combinado com o Art. 30, $§ 4^{\circ}$, do mesmo diploma legal, temse a desconsideração decorrente do abuso de poder de controle indireto pelo voto de empresa controlada detentora de ações da controladora. Já o Art. 117, § 2 ำ prevê que a desconsideração é resultante de ato abusivo do poder por parte do acionista controlador, em favorecimento da sociedade na qual o próprio tenha interesse ou controle (BRUSCHI, 2009).

Ademais, devido à divisão de seu capital em ações, os acionistas terão sua responsabilidade "limitada ao preço de emissão das ações subscritas ou adquiridas" (BRUSCHI, 2009, p. 144). Percebe-se, nesse caso, semelhança às sociedades limitadas, pois, nos dois casos, a responsabilidade do sócio é restrita à "contribuição realizada do capital social" (SILVA, 2009, p. 158). Anote-se, ainda, no que tange às sociedades limitadas, segundo Bruschi (2009), que sua desconsideração normalmente se dá por meio de incidente processual no processo de execução. Já Tomazette (2003, p. 187) defende que implementado o capital social "nada mais pode ser exigido dos sócios patrimonialmente, exceto no caso das hipóteses excepcionais que autorizam a desconsideração da personalidade jurídica", de modo que, no caso da modalidade societária ora analisada, a sua utilização mais recorrente no Brasil se deve ao fato de oferecer menos riscos às partes, o que justifica a não desconsideração da personalidade jurídica.

Não se pode ignorar, contudo, que, na sociedade empresária limitada, a responsabilidade do sócio poderá ser excepcionada diante da execução de créditos tributários, previdenciários e trabalhistas, assim como na constituição de sociedade limitada por cônjuges casados em regime de comunhão ou separação total de bens, nos atos que a lei atribua responsabilidade direta do sócio, na confusão patrimonial entre sócio e sociedade e no desvio da finalidade social da empresa. Os dois últimos atos, aliás, configuram, juntamente com o abuso de direito, os pressupostos de aplicação da teoria da Desconsideração da Personalidade Jurídica, a qual objetiva superar tanto o princípio da autonomia patrimonial da sociedade como a limitação de 
responsabilidade de seus sócios, nas hipóteses em que a personalidade jurídica se torna um obstáculo à punição de seus ofensores.

Logo, é importante salientar que o sócio causador da desconsideração não poderá utilizar-se do benefício de ordem, assim como do direito de regresso contra a sociedade, sob o risco de tirar proveito da própria torpeza. Anote-se, ainda, no que tange a superação da personalidade jurídica específica das sociedades limitadas, há discrepância dos estudiosos do direito no que toca a aplicação no âmbito do Direito Tributário. Os defensores do seu uso argumentam que os pressupostos da aplicação da superação da personalidade jurídica restam caracterizados na atuação imbuída de má-fé por parte dos sócios contra terceiros, sob o véu de proteção da pessoa jurídica. Assim, a corrente majoritária, ao contrário da primeira, defende que o Art. 135, III, do Código Tributário Nacional, versa acerca da responsabilidade pessoal dos sócios pelos atos elencados no dispositivo e que a jurisprudência só a aplica na tentativa de encontrar uma solução adequada ao caso específico (BRASIL, 1966).

Já no âmbito trabalhista e consumerista, a aplicação é bem mais abrangente ao se alicerçar na premissa em que o credor é sempre parte hipossuficiente no processo, principalmente na esfera trabalhista, em razão da natureza alimentar dos créditos envolvidos e pela utilização da concepção consumerista sui generis da disregarddoctrine, adotada por analogia à Justiça do Trabalho, cujo dispositivo civilista encontra aplicação subsidiária. No âmbito jurisprudencial, uma das mais recentes decisões no âmbito do Superior Tribunal de Justiça foi proferida no ano de 2011, nos autos do Recurso Especial oํ 1169175/DF, de relatoria do Ministro Massami Uyeda. $\mathrm{Na}$ referida decisão se discutia a confusão patrimonial entre os bens de sociedade limitada e os bens dos sócios, clamando os quotistas pela limitação da penhora às quotas sociais, o que restou afastado pelo Tribunal, apoiando-se no disposto no Art. 591 do Código Civil de 1973, vigente à época, compreendendo-se que a responsabilidade dos sócios se estende aos bens presentes e futuros. A decisão se encontra assim ementada:

RECURSO ESPECIAL - DIREITO CIVIL - ARTIGOS 472, 593, II e 659, $\S$ 4, DO CÓDIGO DE PROCESSO CIVIL - FUNDAMENTAÇÃO 
DEFICIENTE - INCIDÊNCIA DA SÚMULA 284/STF DESCONSIDERAÇÃO DA PERSONALIDADE JURÍDICA DA SOCIEDADE EMPRESÁRIA - MEDIDA EXCEPCIONAL OBSERVÂNCIA DAS HIPÓTESES LEGAIS - ABUSO DE PERSONALIDADE - DESVIO DE FINALIDADE - CONFUSÃO PATRIMONIAL - DISSOLUÇÃO IRREGULAR DA SOCIEDADE - ATO EFEITO PROVISÓRIO QUE ADMITE IMPUGNAÇÃO - BENS DOS SÓCIOS - LIMITAÇÃO ÀS QUOTAS SOCIAIS - IMPOSSIBILIDADE RESPONSABILIDADE DOS SÓCIOS COM TODOS OS BENS PRESENTES E FUTUROS NOS TERMOS DO ART. 591 DO CPC RECURSO ESPECIAL PARCIALMENTE CONHECIDO E, NESSA EXTENSÃO, IMPROVIDO. I - [...]. II - A desconsideração da personalidade jurídica é um mecanismo de que se vale o ordenamento para, em situações absolutamente excepcionais, desencobrir o manto protetivo da personalidade jurídica autônoma das empresas, podendo o credor buscar a satisfação de seu crédito junto às pessoas físicas que compõem a sociedade, mais especificamente, seus sócios e/ou administradores. III - [...]. IV - A desconsideração não importa em dissolução da pessoa jurídica, mas se constitui apenas em um ato de efeito provisório, decretado para determinado caso concreto e objetivo, dispondo, ainda, os sócios incluídos no polo passivo da demanda, de meios processuais para impugná-la. V - A partir da desconsideração da personalidade jurídica, a execução segue em direção aos bens dos sócios, tal qual previsto expressamente pela parte final do próprio art. 50, do Código Civil e não há, no referido dispositivo, qualquer restrição acerca da execução, contra os sócios, ser limitada às suas respectivas quotas sociais e onde a lei não distingue, não é dado ao intérprete fazêlo. VI - O art. 591 do Código de Processo Civil é claro ao estabelecer que os devedores respondem com todos os bens presentes e futuros no cumprimento de suas obrigações, de modo que, admitir que a execução esteja limitada às quotas sociais levaria em temerária e indevida desestabilização do instituto da desconsideração da personalidade 
jurídica que vem há tempos conquistando espaço e sendo moldado às características de nosso ordenamento jurídico. VII - Recurso especial parcialmente conhecido e, nessa extensão, improvido (BRASIL, 2011).

Percebe-se que o órgão julgador, ainda que de forma indireta, destacou a possibilidade de execução dos bens dos sócios, seja ou não administrador, determinando que os bens presentes e futuros respondam pela execução. Logo, embora seja a desconsideração da personalidade jurídica excepcional, uma vez caracterizado o excesso de mandato, desvio de finalidade, confusão patrimonial ou nas hipóteses de dissolução irregular, há de se levantar o manto da pessoa jurídica para alcançar os bens dos sócios. No ano anterior, quando do julgamento do Recurso Especial $n \cong 1200850 / S P$ o mesmo órgão julgador já havia se pronunciado quanto à possibilidade de constrição dos bens dos sócios em execução, já que a responsabilização dos administradores e sócios pelas obrigações imputadas à pessoa jurídica encontrava amparo na teoria da Desconsideração da Personalidade Jurídica. Portanto, inexistindo separação do patrimônio da pessoa jurídica e seus sócios, ainda que não seja o administrador, a execução pode recair sobre os bens, como se extrai da ementa a seguir:

RECURSO ESPECIAL - NEGATIVAÇÃO DE PRESTAÇÃO JURISDICIONAL - NÃO OCORRÊNCIA - ALEGAÇÃO DE VIOLAÇÃO DA COISA JULGADA - NÃO VERIFICAÇÃO - MOTIVAÇÃO UTILIZADA NA SENTENÇA QUE TRANSITOU EM JULGADO - NÃO INCIDÊNCIA DO EFEITO DA IMUTABILIDADE - DESCONSIDERAÇÃO DA PERSONALIDADE JURÍDICA DA EMPRESA - PREENCHIMENTO DOS REQUISITOS - VERIFICAÇÃO - REVOLVIMENTO DA MATÉRIA FÁTICA-PROBATÓRIA - IMPOSSIBILIDADE - RECURSO IMPROVIDO.

I- [...]; II - A responsabilização dos administradores e sócios pelas obrigações imputáveis à pessoa jurídica, em regra, não encontra amparo tão-somente na mera demonstração de insolvência para o cumprimento de suas obrigações (Teoria menor da desconsideração da personalidade jurídica). Faz-se necessário para tanto, ainda, ou a demonstração do 
desvio de finalidade (este compreendido como o ato intencional dos sócios em fraudar terceiros com o uso abusivo da personalidade jurídica), ou a demonstração da confusão patrimonial (esta subentendida como a inexistência, no campo dos fatos, de separação patrimonial do patrimônio da pessoa jurídica ou de seus sócios, ou, ainda, dos haveres de diversas pessoas jurídicas; III - [...; V - Recurso Especial improvido (BRASIL, 2010).

Anos antes o Superior Tribunal de Justiça, em decisão nos autos de execução fiscal, destacou que os bens dos sócios não respondem, solidariamente, pelas dívidas contraídas pela pessoa jurídica. De fato, se fazem necessários alguns requisitos para que se desconsidere a personalidade jurídica. E acrescentou que somente se justifica a responsabilização no âmbito tributário do sócio-gerente, administrador, diretor ou equivalente se caracterizada a dissolução irregular da sociedade ou comprovada infração à lei. Logo, não basta ser o sócio administrador da sociedade limitada para responder com seus bens. Moraes (2002) explica que o administrador-infrator passa a responder pelo crédito tributário derivado de atos praticados com excesso de poderes ou com infração legal, contratual ou estatutária, excluindo da consequência desses atos o sujeito passivo primário.

Portanto, o redirecionamento de que trata o Art. 135, III, do CTN, é um mecanismo utilizado pelo Fisco, destinado a imputar ao administrador da pessoa jurídica a responsabilidade pelo pagamento de uma obrigação tributária que deixou de ser cumprida pelo devedor originário em decorrência da prática de atos dolosos, direcionados à lesão do erário. Nesse aspecto, diferenciam-se fundamentalmente do Art. 134 do CTN, que se contenta com a participação (por ação ou omissão) do terceiro para responsabilizá-lo subsidiariamente (AMARO, 2007). A propósito, para que ocorra o redirecionamento previsto no Art. 135, III, do CTN, não basta o simples inadimplemento tributário. Há a necessidade de que o administrador pratique, efetiva e comprovadamente, atos com excesso de poderes ou com infração de lei, do contrato social ou estatutos. 
Do contrário, não há que se falar em responsabilidade pessoal. A norma inserida no Art. 135, III, do CTN, diz respeito à responsabilização exclusiva do administradorinfrator por substituição, pela liquidação da obrigação tributária nascida em razão de atos praticados com excesso de poderes, infração de lei, contrato social ou estatutos, sendo que o mero inadimplemento tributário, por si só, não caracteriza ilegalidade. Já em detrimento da responsabilidade tributária de terceiros e seus efeitos sobre os sócios de sociedades comerciais, o Egrégio Superior Tribunal de Justiça editou as súmulas 430 e $435 \mathrm{com}$ o intuito de resolver definitivamente os dois maiores problemas interpretativos a respeito: o inadimplemento e a dissolução irregular da sociedade que levam a responsabilização de sócios.

De acordo com Becho (2013), a súmula 430 está em consonância com a legislação comercial, mais precisamente com o Decreto 3.708/1919 e, também, com a Lei no $6.404 / 1976$, entendendo que se a sociedade comercial apenas deixar de pagar o tributo, não é possível que a cobrança passe a ser feita no patrimônio de seu sócio gerente. A súmula pacificou o entendimento jurisprudencial contra diversas interpretações que tentaram incluir o não pagamento dos tributos como atos praticados com violação do contrato ou da lei ou como ato irregular de gestão ou, ainda, como causa para a impossibilidade do cumprimento da obrigação pela pessoa jurídica. Portanto, o mero inadimplemento da obrigação tributária não enseja responsabilização dos sócios gerentes. Diante do pequeno número de decisões, buscou-se, por meio de uma pesquisa aleatória, decisões prolatadas nos últimos 5 anos no âmbito dos Tribunais Regionais do Trabalho.

A primeira decisão aqui comentada foi proferida pelo Tribunal Regional do Trabalho da $5^{\text {a }}$ Região, que, de forma expressa, ressalta que o sócio não administrador responde pelos débitos da sociedade, não só por ter eventualmente usufruído dos seus lucros, como em face de sua negligência e omissão quanto aos atos de administração ou de má-gestão do sócio administrador (BAHIA, 2014). No mesmo período também se encontra decisão no âmbito do Tribunal de Justiça de Justiça do Rio Grande do Norte, na qual restou assentada que não se pode confundir a pessoa jurídica com a pessoa dos seus sócios, somente respondendo com o seu patrimônio 
aquele que exerce cargo de direção, gerencia ou atua como representante da pessoa jurídica ao infringir a lei, contrato social ou estatuto. Desta feita, não havendo provas de que o sócio não administrador exerceu algum ato de gerência, não pode ser responsabilizado (RIO GRANDE DO NORTE, 2017).

Resta evidente, portanto, que não há consenso no âmbito jurisprudencial quanto à responsabilização do sócio não administrador, encontrando-se decisões que determinam a sua responsabilidade enquanto outras a afastam. Tratando-se da responsabilidade no âmbito do Direito Tributário parece uníssono o entendimento de que o administrador responde pessoal e subjetivamente, de forma substitutiva por atos abusivos ou intencionais, não sendo o simples inadimplemento hábil a afastar a personalidade jurídica.

\section{CONSIDERAÇÕES FINAIS}

Buscou-se compreender, ao longo do presente estudo, a possibilidade de execução dos bens do sócio não administrador no âmbito da sociedade limitada por força da aplicação da teoria da Desconsideração da Personalidade Jurídica. Constatou-se que o ordenamento jurídico pátrio consoante às disposições incluídas no âmbito do Código de Defesa do Consumidor e do Código Civil, adota essa linha teórica, uma vez que a referida teoria fundamenta sua criação na vontade do homem, a qual resulta na aquisição de direitos e obrigações decorrentes da declaração de vontade ou de imposição da lei. Anote-se que a ausência de complexidade das sociedades limitadas, associada com a responsabilidade limitada dos sócios diante de um eventual prejuízo, tornou-se fator essencial ao desenvolvimento da economia por encorajar a atividade empresarial e por contribuir com o aumento da concorrência e, dessa maneira, possibilita a redução do custo de bens e serviços.

Aos sócios são garantidos certos direitos e deveres perante à sociedade limitada. Em outras palavras, deve, o sócio, após a constituição da personalidade jurídica, cooperar para o desenvolvimento da empresa, assim como integralizar o capital social e responder perante terceiros. Igualmente, terá o direito tanto de participar dos lucros como o de fiscalizar, votar e exercer direito de preferência e recesso. Isso se deve 
porque, com os efeitos da personificação da sociedade, tem-se a sua transformação em sujeito de direito com a capacidade de gerir e intervir em sua atividade empresarial e possuir patrimônio próprio, fato este que lhe obriga a responder frente à terceiros pelas suas dívidas e obrigações. Tais direitos e obrigações consagram o princípio da autonomia patrimonial da sociedade em relação aos seus sócios. Ou seja, passa-se a conferir à sociedade patrimônio próprio e responsabilidade ilimitada sobre ele, capacidade para atuar em juízo e aptidão para exercer direitos e deveres próprios.

Contudo, essa autonomia patrimonial é apenas relativa, pois abarca tão somente as relações inter empresariais, não abrangendo a totalidade dos atos em que os sócios poderão ser responsabilizados judicialmente. Afinal, como em qualquer outra área, a atividade empresarial está sujeita a atos fraudulentos de seus sócios, quando então poderá ser afastada a personalidade jurídica e alcançados bens dos sócios em execução. Entretanto, a desconsideração da personalidade jurídica, tal como é hoje concebida, pauta-se no abuso da personalidade da pessoa jurídica. Desta feita, não é possível se atribuir responsabilização aos sócios perante a mera insolvência da empresa ou insatisfação do credor. Entretanto, restando clara a hipótese de atos fraudulentos, será preciso levantar o véu da autonomia patrimonial, permitindo-se, assim, ainda que de forma episódica, a aplicação da desconsideração da personalidade jurídica da sociedade, recaindo a responsabilização do sócio perpetuador da fraude, seja ele administrador ou não.

Cumpre destacar, de igual modo, que a desconsideração da personalidade jurídica apenas terá a sua aplicação justificada em circunstâncias nas quais o ato lícito da pessoa jurídica possa vir a ser considerado ilícito quando caracterizada a má-fé do sócio, de maneira a permitir a desconsideração da personalidade jurídica, com o intuito de atribuir responsabilidade ao sócio. Anote-se que a limitação da responsabilidade dos sócios poderá ser excepcionada quando houver a execução de créditos trabalhistas, previdenciários ou tributários, bem como em razão da constituição, por cônjuges casados, sob o regime de separação ou comunhão total de bens, de sociedade limitada, nos atos que a lei atribua responsabilidade direta do 
sócio, na confusão patrimonial entre sócio e sociedade e no desvio da finalidade social da empresa.

Diante das reflexões aqui elencadas, cabe ressaltar, dessa forma, que os dois últimos atos, aliás, configuram, juntamente com 0 abuso de direito, os pressupostos necessários à aplicação, e, também, à efetivação da teoria da Desconsideração da Personalidade Jurídica, a qual objetiva superar tanto o princípio da autonomia patrimonial da sociedade quanto a limitação de responsabilidade dos sócios, sendo esses administradores ou não, nas hipóteses em que a personalidade jurídica vir a ser obstáculo à punição de seus ofensores. Importante salientar, também, que o sócio causador da desconsideração não poderá utilizar-se do benefício de ordem, assim como do direito de regresso contra a sociedade, sob pena de tirar proveito da própria torpeza.

Desse modo, por todo o exposto, tem-se evidenciada a necessidade de análise do caso concreto, principalmente porque a jurisprudência oscila quanto à responsabilização ou não do sócio quotista que não exerce cargo de gerência, direção ou congênere, embora perceba-se a preocupação em evidenciar o abuso de direito, pressuposto estabelecido na legislação brasileira para aplicação da desconsideração da personalidade jurídica.

\section{REFERÊNCIAS}

ALMEIDA, A. P. de. Manual das sociedades comerciais. 10ª ed. São Paulo: Saraiva, 1998.

AMARO, L. Direito tributário brasileiro. 13ª ed. São Paulo: Saraiva. 2007.

BAHIA. Tribunal Regional da 5a Região. Agravo de Petição no 00495001520045050201/BA, Relator Desembargador Edilton Meireles, publ. 12 ago. 2014. Disponível em: https://trt-5.jusbrasil.com.br/jurisprudencia/159035211/agravode-peticao-ap-495001520045050201-ba-0049500-1520045050201. Acesso em: 03 ago. 2019. 
$\mathrm{BECHO}$, R. L. A compensação entre os prejuízos e os lucros apurados por controladas e coligadas no exterior e o registro do Imposto de Renda diferido: a mensuração do prejuízo do exterior. São Paulo: Dialética, 2013.

BRASIL. Casa Civil. Lei n. 10.406, de 10 de janeiro de 2002. Institui o Código Civil. Disponível em: http://www.planalto.gov.br/ccivil_03/leis/2002/l10406.htm. Acesso em: 03 ago. 2019.

BRASIL. Lei no 5.172, de 25 de outubro de 1966: Dispõe sobre o Sistema Tributário Nacional e institui normas gerais de direito tributário aplicáveis à União, Estados e Municípios. Disponível em: http://www.planalto.gov.br/ccivil_03/leis/L5172.htm. Acesso em: 03 ago. 2019.

BRASIL. Lei no 5.869, de 11 de janeiro de 1973: Institui o Código de Processo Civil. Disponível em: http://www.planalto.gov.br/ccivil_03/leis/L5869compilada.htm. Acesso em: 03 ago. 2019.

BRASIL. Lei no 8.078, de 11 de setembro de 1990: Dispõe sobre a proteção do consumidor e dá outras providências. Disponível em: http://www.planalto.gov.br/ccivil_03/leis//8078.htm. Acesso em: 03 ago. 2019.

BRASIL. Superior Tribunal de Justiça. Agravo Regimental no Recurso Especial no 1034247/SP, Relator Ministro José Delgado, Primeira Turma, publ. 04 jun. 2008. Disponível

em: http://www.stj.jus.br/SCON/jurisprudencia/toc.jsp?livre=\%22execu\%E7\%E30\%2 $2+\% 22 \mathrm{bens}+\mathrm{do}+\mathrm{s} \% \mathrm{~F} 3 \mathrm{cio} \% 22+\% 22 \mathrm{administrado} \% 22 \& \& \mathrm{~b}=\mathrm{ACOR} \&$ thesaurus=JURI DICO\&p=true. Acesso em: 03 ago. 2019.

BRASIL. Superior Tribunal de Justiça. Recurso Especial 1169175/DF, Relator Ministro Massami Uyeda, Terceira Turma, publ. 04 abr. 2011. Disponível em: http://www.stj.jus.br/SCON/jurisprudencia/toc.jsp?livre=\%22execu\%E7\%E30\%22+\% $22 \mathrm{bens}+\mathrm{do}+\mathrm{s} \% \mathrm{~F} 3 \mathrm{cio} \% 22+\% 22$ administrador $\% 22 \& \& \mathrm{~b}=\mathrm{ACOR} \&$ thesaurus $=J U R I D I C O$ $\& p=$ true. Acesso em: 03 ago. 2019. 
Brasil. Superior Tribunal de Justiça. Recurso Especial 1200850/SP, Relator Ministro Massami Uyeda, Terceira Turma, publ. 04 nov. 2010a. Disponível em: http://www.stj.jus.br/SCON/jurisprudencia/toc.jsp?livre=\%22execu\%E7\%E30\%22+\% 22bens+do+s\%F3cio\%22+\%22administrador\%22\&\&b=ACOR\&thesaurus=JURIDICO \&p=true. Acesso em: 03 ago. 2019.

BRUSCHI, G. Aspectos Processuais da Desconsideração da Personalidade Jurídica. $2^{\mathrm{a}}$ ed. São Paulo: Saraiva, 2009.

CALÇAS, M. de. Q. P. Sociedade limitada no novo código civil. São Paulo: Atlas, 2003.

CAMPINHO, S. O direito de empresa à luz do novo código civil. $12^{a}$ ed. rev. e atual. Rio de Janeiro: Renovar, 2011.

CARDOSO, P. L. V. O empresário de responsabilidade limitada. São Paulo: Saraiva 2012.

CARVALHOSA, M. Comentários ao Código Civil. 2ª ed. São Paulo: Saraiva, 2005.

COELHO, F. U. Manual de direito comercial. São Paulo: Saraiva, 2014.

GUIMARÃES, F. L. Desconsideração da pessoa jurídica no código de defesa do Consumidor: aspectos processuais. São Paulo: Max Limonad, 1998.

MORAES, O. de. A analogia no direito tributário. São Paulo: Revista dos Tribunais, 2002.

NEGRÃO, R. Manual de direito comercial e de empresa. $4^{a}$ ed. São Paulo: Saraiva, 2005.

NERY JUNIOR, N.; NERY, R. M. de. A. Comentários ao Código de Processo Civil. São Paulo: Revista dos Tribunais, 2015. 
NEVES, D. A. A. Código de Processo Civil - Lei 13.105/2015: Inovações, alterações, supressões. Rio de Janeiro: Forense; São Paulo: MÉTODO, 2015.

RAMOS, A. L. S. C. Direito empresarial esquematizado. 3를 ed. Rio de Janeiro: Forense; São Paulo: Método, 2014.

REQUIÃO, R. Curso de direito comercial. 25르 ed. atual. São Paulo: Saraiva, 2003.

SILVA, A. C. A aplicação da desconsideração da personalidade jurídica no direito brasileiro. $2^{\mathrm{a}}$ ed. Rio de Janeiro: Forense, 2009.

TARTUCE, F. O novo CPC e o direito civil: impactos, diálogos e interações. Rio de Janeiro: Forense; São Paulo: Método, 2015.

TEIXEIRA, T. Direito empresarial sistematizado: doutrina, jurisprudência e prática. $3^{a}$ ed. São Paulo: Saraiva, 2014.

TOMAZETTE, M. Direito societário. v. 1.2. ed. São Paulo: Juarez de Oliveira, 2003.

Tribunal de Justiça do Rio Grande do Norte. Apelação Cível AC 20160147558/RN, Relator Desembargador Cláudio Santos, Primeira Câmara Cível, julg. 21 set. 2017. Disponível em: https://tj-rn.jusbrasil.com.br/jurisprudencia/504883938/apelacao-civelac-20160147558-rn. Acesso em: 03 ago. 2019.

VENOSA, S. de. S. Direito civil: parte geral. v. 1. 13. ed. São Paulo: Atlas, 2013.

Enviado: Maio, 2020.

Aprovado: Junho, 2020. 